\title{
Cost Analysis of Clinical Compounding in Saudi Arabia: Antibiotic Pediatrics Formulations
}

\author{
Yousef Ahmed Alomi* ${ }^{(D,}$ \\ General Administration of Pharmaceuti- \\ cal Care, Ministry of Health, Riyadh, Saudi \\ Arabia. \\ Malika Alhadab, Head, Pharmacy \\ Services, Alyamma Hopsital, Ministry of \\ Health, Riyadh, Saudi Arabia. \\ Faiz Bahadig, Informatics Pharmacist, \\ Pharmaceutical Care Department, King \\ Abdul-Aziz Medical, City-WR-Jeddah, Minis- \\ try of National Guard, Saudi Arabia. \\ Mohammad Jabir Al Harbi, \\ Neonatology and Pediatrics Clinical \\ Pharmacist, Pharmaceutical Care Services, \\ King Abdulaziz Medical City - Jeddah, Saudi \\ Arabia, Ministry of National Guard-Health \\ Affairs, Saudi Arabia. \\ Mona Lubbad, Former Head, Ex- \\ temporaneous Preparation Unit, Pharmacy \\ services, Alyamma Hopsital, Ministry of \\ Health, Riyadh, Saudi Arabia. \\ Ebtesam Nazal, Head, Extempora- \\ neous Preparation Unit, Pharmacy Services, \\ Alyamma Hopsital, Ministry of Health, \\ Riyadh, Saudi Arabia.
}

\section{Correspondence:}

\section{Dr. Yousef Ahmed Alomi, The Former} General Manager of General Administration of Pharmaceutical Care, Former Head, National Clinical pharmacy and pharmacy practice, Former Head, Pharmacy R\&D Administration, Ministry of Health, P.O.BOX 100, Riyadh-11392, Saudi Arabia.

Phone no: +966 504417712

E-mail:yalomi@gmail.com

\section{Received: 14-10-2018;}

Accepted: 03-02-2019

Copyright: ( ) the author(s), publisher and licensee International Journal of Pharmacology and Clinical Sciences. This is an open-access article distributed under the terms of the Creative Commons Attribution Non-Commercial License, which permits unrestricted non-commercial use, distribution, and reproduction in any medium, provided the original work is properly cited.

This is an open access article distributed under the terms of the Creative Commons Attribution-NonCommercial-ShareAlike 4.0 License

Access this article online

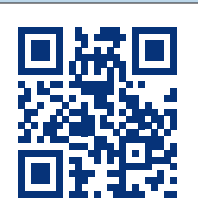

www.ijpcs.net

DOI:

10.5530/ijpcs.2019.8.37

\begin{abstract}
Objectives: The aim of this study to explore the cost analysis of selected pediatrics antibiotics formularies in the Kingdom of Saudi Arabia. Methods: It is a retrospective cost analysis of pediatrics formulations at 300-beds pediatrics and maternity hospital in Riyadh city, Saudi Arabia. The pharmacy section received the specific formulation from physician then the expert pharmacist applied the international standard of clinical compounding through providing to healthcare staff over eight hours per days for five days per a week. The pediatrics formulations consisted of selected four antibiotics (Nitrofurantoin, Oseltamivir, Chloroquine and Clindamycin). The analysis of the cost included the variable expenses included personal cost, material and supply cost, Costs fixed including direct cost, non-salary cost and overhead cost. The cost was derived from the Ministry of Health information database. All cost used US dollar currency. The study analyzed the cost of anti-hypertension pediatrics formulations through the Microsoft Excel sheet version 10th. Results: The estimated average total standard cost of pediatrics formulations per hour was (53.82 USD). The average estimated cost of Nitrofurantoin per each preparation was (14.13 USD) which consisted of standard cost (0.31 USD) and the direct cost was (13.82 USD). The average estimated cost of Oseltamivir per each preparation was (16.95 USD) which consisted of standard cost (0.33 USD) and the direct cost was (16.62 USD). The average estimated cost of Chloroquine per each preparation was (6.645 USD) which consisted of standard cost $(4.36$ USD) and the direct cost was (6.645 USD). The average estimated cost of Clindamycin per each preparation was (14.478 USD) which consisted of standard cost (2.018 USD) and the direct cost was (12.46 USD). Conclusion: There are varieties in the cost analysis between selected pediatric formulation and manufactured ready-made products. The pharmacist should select the cheapest one among them. The cost analysis of pediatrics formulation was used for health insurance coverage and to meet the updated pharmacy strategic plan and Saudi vision 2030 in the Kingdom of Saudi Arabia.

Keywords: Cost, Clinical, Compounding, Antibiotic, Pediatrics, Formulations, Ministry of Health, Saudi Arabia.
\end{abstract}

\section{INTRODUCTION}

In the late year 2012, the general administration of pharmaceutical care released the pharmacy strategic plan of the Ministry of Health institutions. ${ }^{[1]}$ In 2017, the updated Pharmacy strategic plan with new Saudi idiom 2030 had been released. ${ }^{[2]}$ In both strategies, the common goal included was the pharmacoeconomic and healthrelated cost. Both concepts consisted of several aspects, for instance; health insurance, cost analysis of pharmacy services, medications prices and impact of cost avoidance of pharmacist and pharmacy-related services. ${ }^{[2]}$ The cost analysis of medications is demandable to calculate the economic income and experience with net results of profit in the budget. Most of the medications, including antibiotics for pediatrics or geriatrics dosage forms prices organized locally through the Saudi Food and Drug Authority. ${ }^{[3]}$ Some of the antibiotic pediatrics dosage form may rarely be used or the company may not manufacture them anymore or some of the antibiotics not even got registered in the Kingdom of Saudi Arabia. Some examples of pediatrics or geriatrics antibiotics formulations were clindamycin syrup and Nitrofurantoin syrup, not used much and not manufactured frequently and may be called orphan drugs. ${ }^{[4,5]}$ Thus, some hospital pharmacies prepare those medications in case of any circumstances occurred. Besides, they need to develop their prices based on the cost analysis. The authors are not familiar with any publications locally about cost analysis of previous antibiotics pediatrics formulations in Saudi Arabia or Gulf and Middle East countries. The aim of this study is to explore the cost analysis of some pediatrics antibiotics formularies in the Kingdom of Saudi Arabia.

\section{METHODS}

It is a retrospective cost analysis of drug information services past one year at 300-beds pediatrics and maternity hospital in Riyadh city, Saudi Arabia. It had inpatient admission and ambulatory care clinics and emergency departments. The hospital had a different specialty for women adults and pediatrics. The hospital treats the common neonatal, pediatrics and women health disease. The hospital had pharmacy serve 
the patient including inpatient pharmacy with unit dose drug distribution system, outpatient pharmacy and extensive extemporaneous pediatrics section and drug information center. The pharmacy computerized physician order entry with an electronic prescription in addition to the pharmacy had medications safety program. The pharmacy has trained clinical and pharmacy student training programs. The extemporaneous section had very evidence-based comprehensive pediatrics formulations for neonates and pediatrics in the central region of Ministry of Health hospitals. The section received the specific formulation from physician then the expert pharmacist applied the international standard of clinical compounding through providing to healthcare staff over eight hours per days for five days per a week. The pediatrics formulations consisted of antibiotics, anti-tuberculosis (TB) medications, anticonvulsant medications, Gastrointestinal (GI) drugs, anti-hypertension medications, Electrolyte supplements, Renal preparations, Diuretics formulation, Steroid perorations and other supportive substances formulation. The analysis of the cost included the variable expenses included personal cost, material and supply cost. Costs were fixed including direct cost, non-salary cost and overhead cost. ${ }^{[6,7]}$ In addition, there were the cost of compounding substances, number of preparations and time of preparations. The price was derived from the Ministry of Health information database. All cost was used as US dollar currency. The study analyzed antibiotics pediatrics formulations through the Microsoft Excel sheet version $10^{\text {th }}$.

\section{RESULTS}

The estimated average total standard cost of pediatrics formulations per hour was (53.82 USD and consisted of $58.58 \%$ (31.53 USD) for personal cost, $25.14 \%$ (13.53 USD) for overhead cost, 3.34\% (1.8 USD) for material and supply cost, $12.93 \%$ (6.96 USD) for non-salary cost (Table 1). The average estimated cost of Nitrofurantoin per each preparation was (14.13 USD) which consisted of standard cost (0.31 USD) and the direct cost was (13.82 USD). The total annual cost of Nitrofurantoin was (1836.9 USD) (Table 2). The average estimated cost of Oseltamivir per each preparation was (16.95 USD) which consisted of standard cost (0.33 USD) and the direct cost was (16.62 USD). The total annual cost of Oseltamivir was (4,068 USD) (Table 3). The average estimated cost of Chloroquine per each preparation was (6.645 USD) which consisted of standard cost (4.36 USD) and the direct cost was (6.645 USD). The total annual cost of Chloroquine was (66.45 USD) (Table 4). The average estimated cost of Clindamycin per each preparation was (14.478
USD) which consisted of standard cost (2.018 USD) and the direct cost was (12.46 USD). The total annual cost of Clindamycin was (144.78 USD) (Table 5).

\section{DISCUSSION}

Several antibiotics registered in the $\mathrm{MOH}$ drug formulary. It included several dosage forms, ${ }^{[8]}$ for adults and pediatrics. Various antibiotics came as ready-made pediatrics formulations in the $\mathrm{MOH}$ drug formulary. For instance; Amoxicillin, Erythromycin, Azithromycin and Amoxicillin-Clavulanic Acid. However, some pediatrics formulations of antibiotics were not continuously available in the current site pharmacy. As a result, for the patients who needed those products, the medications were prepared at extemporaneous unit in the inpatient pharmacy as a part of the new pharmacy strategic plan with new Saudi vision 2030. ${ }^{[2]}$ It recommended determining the cost analysis of the pharmacy services and pharmacy produce. The current study showed the cost calculation for the four selected pediatrics formulations. All the pediatrics formulations shared with the same indirect and different direct cost. The majority of the direct cost came from personal cost and overhead cost. That is related to pharmacist commonly prepare the medications through using a few types of equipment. The cost of Nitrofurantoin had cost less than registered in the USA and UK market while it was not registered in KSA (Table 6). ${ }^{[3,9-11]}$ That related seldom to using in the pediatrics due to adverse reaction to the pediatrics population. The pediatrics formulation of Nitrofurantoin should continue to prepare it because it is cheaper than ready made in the market and currently not registered in the KSA. Oseltamivir syrup had cost less than registered in the market of KSA and UK while not available in USA (Table 6). ${ }^{[3,9-11]}$ The readily available product with good manufactured practice factories locally or internationally. Oseltamivir was the highest consumed from pharmacy budget among the four antibiotics pediatrics formulations discussed in the results above. It suggested to discuss with local manufactures to reduce the price of the ready-made Oseltamivir syrup because of high utilization and consumption of high workload of preparations. If the manufacture refuse to decrease the price, may be better to continue prepare Oseltamivir as extemporaneous product in the pharmacy.

The ready-made chloroquine syrup available in the market of KSA and UK while it is not available in the USA (Table 6)..$^{[3,9-11]}$ The cost of readymade antibiotic in KSA less expensive than what prepared in the pharmacy. The chloroquine syrup was more expensive than being marketed in KSA because of seldom use
Table 1: Standard cost analysis of pediatrics formulations (USD).

Cost per hour

Personal

Head compounding pharmacist

27.27

staff compounding pharmacist

4.26

Total

Over Head cost

Rent

Bed

0

Offices

0.46

Chairs

1.54

Computer

0.68

Printer

1.43

Zebra label printer (Direct

Thermal)

Refrigerator

1.66

Balance

0.17

Beakers

0.14

Stainless steel spoon

0.21

Measuring cup

0.25

Measuring Cylinder

0.15

Silicone spoon

0.05

cooker

0.03

Funnel

0.04

Bunchner

0.05

\begin{tabular}{|l|l}
\hline Test tube brush & 0.04
\end{tabular}

Kettle 0.15

Mortar and Pestle

Glass rode

Shelf

3.23

Pen/pencils

0.04

scissors

0.02

Total

Material and supply

Large 0.65

Amber bottle

Syringe

0.12

gloves

0.49

Blue sheet

0.31

Face mask

0.02

Total

Non Salary cost

Education and Training head

6.61

Education and Training staff

0.34

Total 6.96 


\section{Table 2: Cost of Nitrofurantoin $10 \mathrm{mg} / 1 \mathrm{ml}$ (USD).}

Personal

31.53

Over Head cost

13.53

Material and supply

1.8

Non Salary cost

6.96

Total

53.82

Preparation time 45 min per one bottle

40.365

Total of preparation 130 per year, the cost per one $100 \mathrm{ml}$

0.31

Direct cost

Nitrofurantoin $100 \mathrm{mg}=10 \mathrm{tab}$

Oral Plus $50 \mathrm{ml}$

Oral Sweet to $100 \mathrm{ml}$

Total

Grand Total $100 \mathrm{ml}$ per bottle

Annual Grand Total cost

$1,836.90$

\section{References}

1. Ensom MHH, Decarie D. Stability of Nitrofurantoin in Extemporaneously Compounded Suspensions. Can J Hosp Pharm 2006;59:29-33

2. M. Haq ABS, Mohd Din RB, Othman NB, et al. Extemporaneous Formulation. Pharmaceutical Services Division. Ministry of Health Malaysia. 2015

\section{Table 3: Cost of Oseltamivir $15 \mathrm{mg} / 1 \mathrm{ml}$ (USD).}

Personal

31.53

Over Head cost

13.53

Material and supply

1.8

Non Salary cost

6.96

Total

53.82

Preparation time 90 min per one bottle

80.73

Total of preparation 240 per year, the cost per one $100 \mathrm{ml}$

Direct cost

Oseltamivir $75 \mathrm{mg}=20$ cap

Simple syrup to $100 \mathrm{ml}$

Total

16.62

Grand Total $100 \mathrm{ml}$ per bottle

Annual Grand Total cost

$4,068.00$

\section{References}

1. Jew RK, Erush SC, Soo-Hoo W, Amiri E. Extemporaneous Formulation for pediatrics, geriatrics and special needs patients. 2016. $3^{\text {rd }}$ edition. American Society of Health-System Pharmacists, Inc.

\section{Table 4: Cost of Chloroquine $25 \mathrm{mg} / 1 \mathrm{ml}$ (USD).}

Personal

Over Head cost

Material and supply

Non Salary cost

Total

Preparation time 45 min per one bottle

Total of preparation when needed per year (around 10), the cost per one $100 \mathrm{ml}$

Direct cost

Chloroquine $250 \mathrm{mg}=10$ tablet

Universal vehicle to $100 \mathrm{ml}$

Total

Grand Total $100 \mathrm{ml}$ per bottle

Annual Grand Total cost

66.45

\section{References}

1. V. Allen LY, Erickson MA. Stability of Aprazolam, chloroquine phosphate, cisapride, enalapril maleate and hydralazine drochloride in extemporaneously compounded oral liquids. Am J Health-Syst Pharm. 1998; 55: 1915-1920

2. M. Haq ABS, Mohd Din RB, Othman NB, et al. Extemporaneous Formulation. Pharmaceutical Services Division. Ministry of Health Malaysia. 2015

\section{Table 5: Cost of Clindamycin $10 \mathrm{mg} / 1 \mathrm{ml}$ (USD).}

Personal

31.53

Over Head cost

13.53

Material and supply

1.8

Non Salary cost

6.96

Total

53.82

Preparation time 22.5 min per one bottle

20.18

Total of preparation when needed per year ( around 10),

2.018

the cost per one $120 \mathrm{ml}$

Direct cost

Clindamycin $150 \mathrm{mg}$ vial $=8 \mathrm{ml}$

11.4

Universal vehicle to $120 \mathrm{ml}$

1.06

Total

Grand Total $120 \mathrm{ml}$ per bottle

14.478

Annual Grand Total cost

144.78

\section{References}

1. Allen LV. Basic of compounding for terrorist attacks, part 2. International Journal of Pharmaceutical Compounding.2003; 7(2):129-134. 


\begin{tabular}{|c|c|c|c|c|c|c|c|c|}
\hline Medications & \multicolumn{2}{|c|}{ Cost of Current study } & \multicolumn{2}{|c|}{ Cost in KSA (USD) ${ }^{[3]}$} & \multicolumn{2}{|c|}{ Cost in US (USD) ${ }^{[9]}$} & \multicolumn{2}{|c|}{ Cost in UK (USD) ${ }^{[10,11]}$} \\
\hline & Conc. mg/ml & Volume & Conc. mg/ml & Volume & Conc. $\mathrm{mg} / \mathrm{ml}$ & Volume & Conc. mg/ml & Volume \\
\hline $\begin{array}{l}\text { Nitrofurantoin } \\
10 \mathrm{mg} / 1 \mathrm{ml}\end{array}$ & $\begin{array}{c}1 \mathrm{mg} / \mathrm{ml}= \\
0.0141 \$\end{array}$ & $100 \mathrm{ml}=14.13 \$$ & Not available & Not available & $\begin{array}{c}1 \mathrm{mg} / \mathrm{ml}= \\
0.399 \$\end{array}$ & $\begin{array}{c}5 \mathrm{mg} / \mathrm{ml} \\
140 \mathrm{ml}= \\
279.53 \$ \\
(100 \\
\mathrm{ml}=199.66 \$)\end{array}$ & $\begin{array}{c}1 \mathrm{mg} / \mathrm{ml}= \\
0.3752 \$\end{array}$ & $\begin{array}{c}5 \mathrm{mg} / \mathrm{ml} \\
300 \mathrm{ml}=562.86 \$ \\
(100 \mathrm{ml}=187.62 \$)\end{array}$ \\
\hline $\begin{array}{l}\text { Oseltamivir } \\
15 \mathrm{mg} / 1 \mathrm{ml}\end{array}$ & $\begin{array}{c}1 \mathrm{mg} / \mathrm{ml}= \\
0.0113 \$\end{array}$ & $100 \mathrm{ml}=16.95 \$$ & $\begin{array}{l}1 \mathrm{mg} / \mathrm{ml}= \\
0.0249 \$\end{array}$ & $\begin{array}{c}12 \mathrm{mg} / \mathrm{ml} \\
100 \mathrm{ml}=29.88 \$\end{array}$ & Not available & Not available & $\begin{array}{c}1 \mathrm{mg} / \mathrm{ml}= \\
0.033 \$\end{array}$ & $\begin{array}{c}6 \mathrm{mg} / \mathrm{ml} \\
65 \mathrm{ml}=12.929 \$ \\
(100 \mathrm{ml}=19.89 \$)\end{array}$ \\
\hline $\begin{array}{l}\text { Chloroquine } \\
25 \mathrm{mg} / 1 \mathrm{ml}\end{array}$ & $\begin{array}{c}1 \mathrm{mg} / \mathrm{ml}= \\
0.002658 \$\end{array}$ & $\begin{array}{c}100 \mathrm{ml}= \\
6.645 \$\end{array}$ & $\begin{array}{c}1 \mathrm{mg} / \mathrm{ml}= \\
0.00108 \$ \\
\\
1 \mathrm{mg} / \\
\mathrm{ml}=0.00192 \$ \\
1 \mathrm{mg} / \\
\mathrm{ml}=0.00161 \$\end{array}$ & $\begin{array}{c}16 \mathrm{mg} / \mathrm{ml} \\
60 \mathrm{ml}=1.04 \$ \\
(100 \mathrm{ml}=1.733 \$) \\
\\
10 \mathrm{mg} / \mathrm{ml} \\
100 \mathrm{ml}=1.92 \$ \\
24 \mathrm{mg} / \mathrm{ml} \\
60 \mathrm{ml}=2.33 \$ \\
(100 \mathrm{ml}=3.88 \$)\end{array}$ & Not available & Not available & $\begin{array}{c}1 \mathrm{mg} / \mathrm{ml}= \\
0.0314 \$\end{array}$ & $\begin{array}{c}16 \mathrm{mg} / \mathrm{ml} \\
75 \mathrm{ml}=37.78 \$ \\
(100 \mathrm{ml}=50.37 \$)\end{array}$ \\
\hline $\begin{array}{l}\text { Clindamycin } \\
10 \mathrm{mg} / 1 \mathrm{ml}\end{array}$ & $\begin{array}{c}1 \mathrm{mg} / \mathrm{ml}= \\
1.2065 \$\end{array}$ & $\begin{array}{c}120 \mathrm{ml}= \\
14.478 \$ \\
(100 \mathrm{ml}=12.065 \$)\end{array}$ & Not available & Not available & Not available & Not available & Not available & Not available \\
\hline
\end{tabular}

in the local market and few preparations annually. It suggested to hold prepare the product as extemporaneous preparation and buy the product from KSA market. The pharmacy can prepare the product during shortage of stock only. The clindamycin syrup not registered in the local market, USA or UK and it was hard to compare cost with them (Table 6). ${ }^{[3,9-11]}$ The product is seldom used in the hospital as inpatient drug, not outpatient medications and not frequently used in the OPD hospitals because of the presenting of safe alternative medications. The pharmacy may prepare during high demand and when there are no alternatives in the pharmacy. The study explored the cost analysis of some selected antibiotics pediatrics formulations with considerable variation from the market. The policy of orphan, including the cost analysis of drug and that, is should establish and implement in the Kingdom of Saudi Arabia.

\section{CONCLUSION}

The antibiotics commonly prescribed for adults and pediatrics in over the world. Antibiotics adults' oral dosage form is mostly available in the local or international market. However, antibiotics oral pediatrics formulation is available for most used medications except orphan drugs or not commonly used for neonates or pediatrics. Besides, the cost of antibiotics oral pediatric formulation is unknown. The cost analysis of the orphan drug is a crucial element of the pharmacy budget. The determination of cost analysis of antibiotics orphan medications is highly recommended regularly in the kingdom of Saudi Arabia.

\section{ACKNOWLEDGEMENT}

None.

\section{CONFLICT OF INTEREST}

The authors declare no conflict of interest

\section{ABBREVIATIONS}

KSA: Kingdom of Saudi Arabia; USD: United State Dollars; GI: gastrointestinal; GERD: Gastroesophageal reflex diseases; MOH: Ministry of Health; TB: tuber-culosis; SFDA: Saudi Food and Drug Authority; USA: United States of America; UK: United Kingdom; OPD: Outpatient Department.

\section{ORCID ID}

Yousef Ahmed Alomi (D) https://orcid. org/0000-0003-1381-628X

\section{REFERENCES}

1. Alomi YA, Alghamdi SJ, Alattyh RA. Strategic plan of general administration of pharmaceutical care at Ministry of Health in Saudi Arabia 2012-2022. J Pharm Scien. 2015;1(13):1-8.

2. Alomi YA, Alghamdi SJ, Alattyh RA, Elshenawy RA. The Evaluation of Pharmacy Strategic Plan in Past 2013-2016 and Forecasting of New Vision 2030 at Ministry of Health in Saudi Arabia. J Pharm Pract Community Med. 2018;4(2):93-101.

3. Saudi Food and Drug Authority. List of human medicine and herbal health. 2019. [cited 2019 Jun 17]. Available from: https://www.sfda.gov.sa/en/ drug/resources/Pages/DrugsUnderRegistrations. aspx.

4. Mohajer KA, Al-yami SM, Al-jeraisy MI, Abolfotouh MA. Antibiotic prescribing in a pediatric emergency setting in central Saudi Arabia. Saudi Med J. 2011;32(2):197-8.

5. Orphanet: About orphan drugs. 2019. Cited 2019 Jun 10. Available from: https://www.orpha.net/ consor/cgibin/Education_AboutOrphanDrugs. php?lng=EN.

6. Alomi YA, Al-Jarallah SM. The Cost Analysis of Network Drug Information Services at Ministry of Health Institutions in Saudi Arabia. J Pharm Pract Community Med. 2018;4(4):226-30.

7. Alomi YA, Alsulami N, AlQahtani N, Mashouf M, Qahtani A, Almansor FA. Cost Analysis of Drug Information Services at the Mental Hospital in Saudi Arabia. J Pharm Pract Community Med. 2018;4(2):83-6.

8. Ministry of Health. Ministry of Health Formulary. Health Ministry of Health. 2012.

9. Athena Health. Epocrates Online. Epocrates.com. 2017. Available from: https://online.epocrates. com/home.

10. Ah-See KW, et al. Royal Pharmaceutical Society: British National Formulary 76editors. British $\mathrm{Na}$ tional Formulary. BMJ Group. 2019;1-1653.

11. British Medical Association. BNF: For Children. 2017-2018. 